\title{
Pengembangan lembar kerja peserta didik berbasis problem-based learning pada topik sudut
}

\author{
Dandi Mifta Abdillah ${ }^{1}$ iD, Dwi Astuti ${ }^{1 *}$ \\ ${ }^{1}$ Department of Mathematics Education, Universitas Ahmad Dahlan, Yogyakarta, Indonesia \\ * Corresponding Author. E-mail: dwi.astuti@pmat.uad.ac.id
}

\begin{tabular}{|c|c|}
\hline ARTICLE INFO & ABSTRACT \\
\hline $\begin{array}{l}\text { Keywords: } \\
\text { Lembar kerja peserta didik, } \\
\text { Model pengembangan } \\
\text { ADDIE, } \\
\text { Pembelajaran sudut, } \\
\text { Problem-based learning, } \\
\text { Students' worksheet, } \\
\text { Learning of angles topic. }\end{array}$ & $\begin{array}{l}\text { Penelitian ini bertujuan untuk menghasilkan Lembar Kerja Peserta Didik (LKPD) berbasis Pro- } \\
\text { blem-Based Learning (PBL) pada topik sudut yang layak. Penelitian pengembangan ini meng- } \\
\text { adopsi model pengembangan ADDIE dengan tahapan meliputi Analysis, Design, Development, } \\
\text { Implementation, dan Evaluation. Kualitas LKPD ditinjau dari penilaian ahli materi, ahli media, dan } \\
\text { respons peserta didik. Instrumen penelitian yang digunakan adalah angket ahli materi, angket } \\
\text { ahli media, dan angket respons peserta didik. LKPD diujicobakan di kelas VII SMP Muhammadi- } \\
\text { yah } 1 \text { Yogyakarta dengan subjek sebanyak } 32 \text { peserta didik. LKPD yang dikembangkan memuat } \\
\text { aktivitas pembelajaran sesuai langkah PBL, menyajikan masalah yang berkaitan dengan kehi- } \\
\text { dupan sehari-hari di awal pembelajaran, dan dapat digunakan dalam pembelajaran online. Di- } \\
\text { tinjau dariaspek materi, LKPD dinilai baik dengan rerata skor penilaian oleh ahli materiyaitu 4,00. } \\
\text { Ditinjau dari aspek media, LKPD dinilai baik dengan skor penilaian oleh ahli media sebesar 3,60. } \\
\text { Respons peserta didik terhadap penggunaan LKPD termasuk pada kategori baik dengan rerata } \\
\text { skor penilaian sebesar 4,05. Dapat disimpulkan bahwa LKPD berbasis PBL untuk SMP kelas VII } \\
\text { pada topik sudut layak digunakan dalam pelaksanaan pembelajaran matematika. }\end{array}$ \\
\hline
\end{tabular}

Scan me:

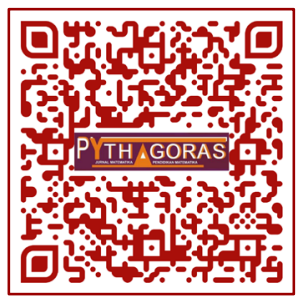

This study aimed to produce a students' worksheet or Lembar Kerja Peserta Didik (LKPD) based on Problem-Based Learning (PBL) on the topic of angles which were feasible. This development research adopted the ADDIE development model with stages including Analysis, Design, Development, Implementation, and Evaluation. The quality of $L K P D$ was viewed from the assessment of material experts, media experts, and students' responses. The instrument used was a material expert questionnaire, a media expert questionnaire, and a students' response questionnaire. LKPD was piloted on 32 seventh-grade students of private junior high schools, namely SMP Muhammadiyah 1 Yogyakarta, Indonesia. The developed LKPD contained learning activities according to PBL steps, presented problems related to everyday life at the beginning of learning, and could be used in online learning. In terms of the material aspect, LKPD was considered good with an average score of assessment by material experts, namely 4.00. In terms of the media aspect, LKPD was considered good with a score of 3.6 by media experts. Students' responses to the use of $L K P D$ were included in the good category with an average score of assessment of 4.05 . It could be concluded that the PBL-based LKPD for seventh-grade junior high school students on the topic of angles was feasible for use in the implementation of mathematics learning.

This is an open access article under the CC-BY-SA license

\section{How to Cite:}

Abdillah, D. M., \& Astuti, D. (2020). Pengembangan lembar kerja peserta didik berbasis problem-based learning pada topik sudut. Pythagoras: Jurnal Pendidikan Matematika, 15(2), 190-200. https://doi.org/10.21831/pg.v15i2.36444

https://doi.org/10.21831/pg.v15i2.36444

\section{PENDAHULUAN}

Menurut Undang-Undang Nomor 20 Tahun 2003 tentang Sistem Pendidikan Nasional (Presiden Republik Indonesia, 2003), tujuan pendidikan nasional adalah untuk mengembangkan kemampuan dan membentuk watak serta peradaban bangsa yang bermartabat dalam rangka mencerdaskan kehidupan bangsa. Untuk membantu tercapainya tujuan pendidikan nasional tersebut, dalam melaksanakan proses pembelajaran di kelas guru dituntut 
untuk kreatif dan inovatif agar tercipta pembelajaran yang menarik dan menyenangkan bagi peserta didik. Guru sebagai salah satu faktor penentu keberhasilan pendidikan. Selain itu, guru juga memiliki peran besar dalam menganalisis setiap komponen yang mempengaruhi proses pembelajaran (Astuti, 2016). Komponen-komponen tersebut meliputi tujuan, materi pelajaran, metode atau strategi pembelajaran, media, dan evaluasi (Sanjaya, 2006). Komponen tersebut saling berinteraksi dan berinterelasi (Sanjaya, 2006). Oleh karena itu, diperlukan analisis terhadap lima komponen pokok dalam proses pembelajaran tersebut agar dapat membantu guru dalam memprediksi keberhasilan proses pembelajaran di kelas, salah satunya dalam proses pembelajaran matematika.

Salah satu model pembelajaran yang direkomendasikan pada Kurikulum 2013 adalah Problem-Based Learning (PBL) (Kemdikbud, 2013). PBL adalah model pembelajaran yang menerapkan teori konstruktivisme (Dolmans et al., 2005). Dalam penerapannya, PBL memberikan kesempatan seluas-luasnya kepada peserta didik untuk menyelidiki permasalahan yang dihadapi. Hal tersebut sejalan dengan empat pilar pendidikan utama yang dirumuskan oleh UNESCO (Sindhunata, 2000), yaitu belajar memahami (learning to know), belajar melaksanakan atau melakukan (learning to do), belajar menjadi diri sendiri (learning to be), belajar bekerja sama atau hidup dalam kebersamaan (learning to live together). Berdasarkan pilar tersebut maka belajar memahami bukan berarti hanya menghafal konsep atau teori saja, tetapi mengetahui makna dari konsep atau teori tersebut. Belajar tidak hanya berorientasi pada hasil, tetapi orientasi utamanya adalah proses belajarnya. Proses belajar juga tidak sekedar mendengar dan melihat untuk menghimpun pengetahuan, tetapi belajar menuntut untuk melakukan sesuatu aktivitas dengan tujuan menguasai kompetensi tertentu. Dengan melakukan aktivitas semacam itu, maka akan memberikan pengalaman untuk menyelesaikan permasalahan yang dihadapi. Penyelesaian masalah dapat dilakukan melalui kerja sama dengan teman sejawat.

Pembelajaran yang menerapkan model PBL merupakan pembelajaran yang dirancang untuk meningkatkan kualitas pembelajaran dengan mewajibkan peserta didik mempelajari materi berdasarkan masalah yang disajikan (Jonassen, 2011). Masalah yang disajikan merupakan masalah yang autentik dan konstektual serta baru sehingga dalam proses pemecahan masalahnya, ada kemungkinan peserta didik belum mengetahui dan memahami semua pengetahuan prasyaratnya (Abidin, 2014; Isrok'atun \& Rosmala, 2018). PBL menyajikan masalah sebagai konteks bagi peserta didik untuk memperoleh keterampilan dan pengetahuan pemecahan masalah (Uden \& Beaumont, 2006). Aktivitas peserta didik dalam menyelesaikan masalah tersebut akan mengasah kemampuan pemecahan masalahnya melalui proses berpikir secara multi perspektif (Abidin, 2014; Isrok'atun \& Rosmala, 2018). PBL berpusat pada peserta didik, mengembangkan pembelajaran aktif, memberikan memotivasi kepada peserta didik dalam pembelajaran, mengembangkan keterampilan peserta didik dalam memecahkan masalah (Ali et al., 2010), dan meningkatkan prestasi belajar peserta didik (Merritt et al., 2017). Untuk mencapai tujuan dalam PBL, peserta didik difasilitasi untuk bekerja dalam kelompok kecil (Botty \& Shahrill, 2015). Peserta didik melakukan aktivitas dalam kelompok-kelompok kecil tersebut untuk menyelesaikan masalah yang berkaitan dengan kehidupan nyata (Chakrabarty \& Mohamed, 2013). Melalui aktivitas tersebut, peserta didik terfasilitasi untuk belajar secara bermakna, mengembangkan kreativitas dan berinovasi, dan juga mengembangkan keterampilan berkolaborasi (Isrok'atun \& Rosmala, 2018).

PBL dilaksanakan dengan mengacu pada enam tahap yang ada (Isrok'atun \& Rosmala, 2018). Pertama, penyajian masalah oleh guru yang selanjutnya akan diselesaikan oleh peserta didik. Kedua, peserta didik mendiskusikan masalah secara berkelompok untuk merumuskan penyelesaian masalah tersebut. Ketiga, peserta didik diberi kebebasan untuk merumuskan penyelesaian masalah tanpa bimbingan dari guru. Peserta didik dapat merumuskan masalah berdasarkan pengetahuan yang dapat diperoleh dari sumber-sumber informasi yang dapat mereka akses. Keempat, peserta didik saling berbagi informasi dalam diskusi kelompok. Kelima, menyajikan hasil diskusi mengenai perumusan dan pemecahan masalah yang ada. Keenam, sebagai tahap akhir, refleksi dan review terhadap proses pembelajaran yang telah dilakukan melalui kegiatan pemecahan masalah.

Berdasarkan hasil observasi yang dilakukan oleh peneliti dalam kegiatan pembelajaran matematika kelas VII di salah satu sekolah menengah pertama swasta, ditemukan bahwa dalam kegiatan pembelajaran, peserta didik hanya menggunakan buku paket dari sekolah saja. Guru belum menggunakan Lembar Kerja Peserta Didik (LKPD) sebagai bahan ajar untuk mendukung kegiatan pembelajaran. LKPD merupakan lembaran yang berisi petunjuk dan langkah-langkah untuk menyelesaikan suatu aktivitas yang harus dikerjakan oleh peserta didik (Majid, 2012). LKPD dikembangkan sesuai dengan kebutuhan peserta didik dan kondisi lingkungan pendidikan (Sugiyanto et al., 2018). Dengan menggunakan LKPD, peserta didik menjadi lebih aktif dalam proses pembelajaran. Pembelajaran yang aktif akan menciptakan interaksi efektif antara guru dan peserta didik sehingga diharapkan peserta didik mampu mene- 
mukan konsep matematika secara mandiri dengan bantuan LKPD tersebut (Relia, 2016). LKPD biasanya memuat enam unsur utama, yaitu judul, petunjuk belajar, Kompetensi Dasar (KD) atau materi pokok, informasi pendukung, tugas atau langkah kerja, dan penilaian (Prastowo, 2011).

Pembelajaran matematika khususnya kelas VII masih cenderung berpusat pada guru sehingga membuat peserta didik pasif dan kurang terlibat dalam pembelajaran (Niken et al., 2012; Siregar, 2013). Sedangkan tujuan utama kegiatan pembelajaran sendiri untuk memberikan pengalaman belajar bagi peserta didik yang melibatkan proses mental dan fisik melalui interaksi antar peserta didik dan guru. Oleh karena itu, guru harus merencanakan suatu pembelajaran matematika yang menarik dan bermakna untuk menyelesaikan permasalahan peserta didik terkait kurangnya terlibat secara aktif dalam aktivitas pembelajaran. Salah satunya dapat menggunakan bahan ajar yang dapat membantu kegiatan dalam pembelajaran matematika. Bahan ajar yang banyak digunakan oleh peserta didik berupa buku cetak yang disediakan oleh pihak sekolah. Peserta didik masih kurang berminat membaca buku paket matematika yang ada karena bukunya sangat tebal dan kurang menarik (Oktaviana \& Prihatin, 2019; Salyani et al., 2018). Untuk mengatasi hal tersebut, guru dapat membuat bahan ajar yang lebih sederhana yang dapat disenangi peserta didik, salah satunya dengan LKPD.

Beberapa penelitian yang berkaitan dengan pengembangan LKPD berbasis PBL sudah dilakukan (misalnya, Perwitasari \& Surya, 2017; Risfalidah et al., 2019; Siagian et al., 2019). LKPD matematika berbasis PBL yang dihasilkan melalui penelitian pengembangan tersebut dapat meningkatkan kemampuan komunikasi dan disposisi matematis peserta didik kelas XI SMK (Risfalidah et al., 2019), kemampuan komunikasi matematis peserta didik kelas VII SMP (Perwitasari \& Surya, 2017), serta dapat meningkatkan kemampuan pemecahan masalah peserta didik kelas VII SMP (Amalia et al., 2017; Siagian et al., 2019). Lebih lanjut, penelitian pengembangan yang dilakukan oleh Perwitasari dan Surya (2017) berfokus pada topik statistika kelas VII SMP, Risfalidah et al. (2019) berfokus pada topik matriks kelas XI SMK, dan Siagian et al. (2019) berfokus pada topik aritmetika kelas VII SMP. Dengan demikian, penelitian ini berfokus untuk menghasilkan LKPD berbasis PBL pada topik sudut kelas VII SMP. Dengan dihasilkannya LKPD melalui penelitian ini diharapkan dapat membantu peserta didik untuk terlibat secara aktif dalam pembelajaran, lebih termotivasi dalam membaca buku, dan memahami materi pembelajaran secara lebih mudah.

\section{METODE}

Jenis penelitian yang dilakukan adalah penelitian pengembangan. Metode penelitian pengembangan adalah metode penelitian yang digunakan untuk menghasilkan produk tertentu dan menguji keefektifan produk tersebut (Sugiyono, 2016). Model pengembangan yang digunakan adalah Analyze, Design, Development, Implementation, dan Evaluation (ADDIE). Subjek dalam penelitian ini terdiri atas 32 peserta didik kelas VII B SMP Muhammadiyah 1 Depok, Sleman. Uji coba dilakukan sebanyak 3 kali pertemuan pada bulan Mei 2020. Uji coba dilakukan secara online melalui WhatsApp group karena adanya pandemi Covid-19.

Instrumen yang digunakan dalam penelitian ini adalah angket ahli materi, angket ahli media, dan angket respons peserta didik. Angket ahli materi merupakan ditujukan untuk menilai produk ditinjau dari materi yang dikembangkan dalam LKPD berbasis PBL. Angket ahli materi dikembangkan dengan skala Likert dengan skor 1, 2, 3,4 , dan 5 . Angket ini terdiri atas 34 butir pernyataan yang mewakili tiga aspek penilaian, yaitu kelayakan isi, kelayakan penyajian, dan kesesuaian dengan PBL. Secara lebih spesifik, aspek kelayakan isi berfokus pada penilaian teradap kesesuaian materi dengan Kompetensi Inti (KI) dan Kompetensi Dasar (KD), keakuratan materi, dan kemutakhiran materi. Aspek kelayakan penyajian berfokus pada penilaian terhadap penyajian materi dan koherensi alur berpikir. Adapun aspek kesesuaian dengan PBL berfokus pada penilaian terhadap kesesuaian muatan LKPD dengan hakikat dan komponen PBL. Selanjutnya, angket ahli media digunakan untuk menilai kesesuaian LKPD berbasis PBL dengan kaidah-kaidah penyajian bahan ajar. Angket ahli media dikembangkan dengan skala Likert dengan skor 1 , 2,3 , 4, dan 5 . Angket ini terdiri atas 36 butir pernyataan yang merefleksikan dua aspek penilaian, yaitu kelayakan kegrafikan dan kelayakan bahasa. Aspek kelayakan kegrafikan meliputi penilaian terhadap ukuran LKPD, desain sampul LKPD, dan desain isi LKPD. Sedangkan aspek kelayakan bahasa meliputi penilaian terhadap kekomunikatifan LKPD, keinteraktifan LKPD, kesesuaian muatan LKPD dengan perkembangan peserta didik, kesesuaian kaidah bahasa yang digunakan, dan penggunaan simbol. Terakhir, angket respons peserta didik digunakan untuk mengetahui respons peserta didik setelah menggunakan LKPD berbasis PBL yang dikembangkan dalam penelitian ini. Angket respons peserta didik dikembangkan dengan menggunakan skala Likert dengan skor 1, 2, 3, 4, dan 5. Angket ini terdiri atas 16 butir pernyataan yang mewakili tiga aspek penilaian, yaitu materi, kebahasaan, dan ketertarikan. Aspek materi berkaitan dengan penilaian peserta didik terhadap keterkaitan masalah yang ada dalam LKPD dengan 
kehidupan sehari-hari dan sistematika penyajian. Aspek kebahasaan berhubungan dengan penilaian peserta didik terhadap penggunaan kalimat dan huruf dalam LKPD. Adapun aspek ketertarikan berkaitan dengan penilaian peserta didik terhadap tampilan LKPD, motivasi peserta didik untuk belajar dengan menggunakan LKPD, dan kemandirian belajar dengan LKPD.

Data yang terkumpul dari penilaian ahli materi, penilaian ahli media, dan respons peserta didik dianalisis untuk mengetahui kelayakan dari LKPD berbasis PBL. Analisis data dilakukan dengan cara menentukan rata-rata skor dari masing-masing penilaian dan selanjutnya dikategorikan berdasarkan kriteria yang disajikan dalam Tabel 1. Media pembelajaran berupa LKPD berbasis PBL dikatakan layak untuk digunakan jika hasil penilaian ahli materi dan ahli media berada pada kategori minimal baik dan rata-rata skor respons peserta didik minimal pada kategori baik.

Tabel 1. Kriteria kelayakan LKPD berdasarkan ahli materi, ahli media, dan respons peserta didik

\begin{tabular}{ll}
\hline Interval rata-rata skor & Kategori \\
\hline $\bar{x}>4,2$ & Sangat baik \\
$3,4<\bar{x} \leq 4,2$ & Baik \\
$2,6<\bar{x} \leq 3,4$ & Cukup baik \\
$1,8<\bar{x} \leq 2,6$ & Kurang baik \\
$\bar{x} \leq 1,8$ & Sangat kurang baik \\
\hline
\end{tabular}

Sumber: Widoyoko (2017)

\section{HASIL PENELITIAN}

Media pembelajaran berupa LKPD berbasis PBL pada materi sudut untuk SMP kelas VII diperoleh dengan proses penelitian pengembangan dengan menggunakan model ADDIE yang meliputi tahap analysis (analisis), design (perancangan), development (pengembangan), implementation (implementasi), dan evaluation (evaluasi). Kelima tahap tersebut diuraikan sebagai berikut.

\section{Analysis (Analisis)}

Pada tahap ini dilakukan beberapa analisis untuk memberikan gambaran mengenai kebutuhan bahan ajar yang akan dikembangkan. Peneliti melakukan analisis di SMP Muhammadiyah 1 Depok. Adapun analisis-analisis yang dilakukan untuk mendukung proses pengembangan ini antara lain analisis terhadap kebutuhan bahan ajar, analisis terhadap cakupan materi, dan analisis terhadap kurikulum yang ada. Pada tahap analisis kebutuhan bahan ajar, dilakukan observasi dan wawancara kepada guru matematika dan beberapa peserta didik kelas VII di SMP Muhammadiyah 1 Depok. Tahap ini bertujuan untuk mengetahui bahan ajar apa yang dibutuhkan di SMP tersebut. Berdasarkan hasil wawancara dengan guru, pembelajaran yang dilakukan di kelas masih menggunakan referensi buku paket yang disediakan oleh sekolah saja. Peserta didik menunjukkan bahwa kurang berminat membaca buku karena ada kesan buku tebal dan kegiatan pembelajaran yang ada dalam buku tersebut kurang menarik. Selain itu, juga didapati bahwa proses pembelajaran belum menggunakan bahan ajar lain, misalnya LKPD. Padahal LKPD merupakan salah satu bahan ajar yang dapat membantu untuk meningkatkan hasil belajar peserta didik terutama melalui penerapan PBL (Choo et al., 2011; Nasrullah et al., 2018). Selain itu, LKPD dapat dikembangkan sesuai dengan kebutuhan untuk memfasilitasi peserta didik agar lebih aktif dalam proses pembelajaran (Muslim et al., 2018). Hasil dari tahap ini adalah peneliti akan mengembangkan bahan ajar berupa LKPD berbasis PBL.

Pada tahap analisis materi, peneliti menentukan materi yang akan dikembangkan dalam LKPD. Pemilihan materi dilakukan setelah peneliti melakukan diskusi dengan guru matematika di SMP Muhammadiyah 1 Depok. Berdasarkan diskusi ini, didapati informasi bahwa peserta didik masih mengalami kesulitan pada materi sudut. Hal tersebut didukung dengan daya serap peserta didik di SMP Muhammadiyah 1 Yogyakarta untuk materi sudut pada Ujian Nasional (UN) sebesar 49,28\% (Puspendik, 2019). Peserta didik masih mengalami kesulitan untuk menemukan konsep sudut karena konsep sudut merupakan materi yang abstrak bagi peserta didik (Wardhani, 2013). Padahal topik sudut merupakan salah satu unsur penting untuk membangun konsep dalam geometri bidang dan geometri ruang (Turmudi, 2010). Materi yang dikembangkan dalam LKPD berbasis PBL adalah sudut. Sub materi yang dalam LKPD yaitu mengenal sudut dan hubungan antar sudut, hubungan antar sudut dibagi menjadi beberapa bagian yaitu sudut berpelurus dan berpenyiku, pasangan sudut yang saling bertolak belakang, dan hubungan sudut-sudut pada dua garis sejajar. Kaitan materi sudut dengan metode PBL yaitu peserta didik dapat menemukan masalah dalam kehidupan sehari-hari yang berkaitan dengan sudut seperti contoh mengamati 
sebuah jam dinding, di mana mengamati jam dinding ini termasuk dalam sub bahasan yang pertama yaitu mengenai mengenal sudut. Penyelesaian permasalahan pada LKPD berbasis PBL dilakukan secara berkelompok atau individu.

Pada tahap analisis kurikulum dilakukan kajian terhadap kurikulum matematika di SMP, yang meliputi analisis materi pokok, Kompetensi Inti (KI), Kompetensi Dasar (KD), dan indikator-indikator yang harus dicapai oleh peserta didik. Dilakukannya tahap ini adalah dengan tujuan agar LKPD yang disusun sesuai dengan kebutuhan peserta didik di SMP Muhammadiyah 1 Depok. Hasil analisis kurikulum disajikan dalam Tabel 2.

Tabel 2. Analisis kurikulum untuk mengembangkan LKPD berbasis PBL

\begin{tabular}{|c|c|c|c|}
\hline Kompetensi inti & Kompetensi dasar & Topik & Indikator pencapaian kompetensi \\
\hline $\begin{array}{l}\text { Memahami dan menerapkan } \\
\text { pengetahuan (faktual, konseptual, } \\
\text { dan prosedural) berdasarkan rasa } \\
\text { ingin tahunya tentang ilmu } \\
\text { pengetahuan, teknologi, seni, budaya } \\
\text { terkait fenomena dan kejadian } \\
\text { tampak mata }\end{array}$ & $\begin{array}{l}\text { Menganalisis } \\
\text { hubungan antar } \\
\text { sudut sebagai } \\
\text { akibat dari dua } \\
\text { garis sejajar yang } \\
\text { dipotong oleh garis } \\
\text { transversal }\end{array}$ & $\begin{array}{l}\text { Mengenal } \\
\text { sudut } \\
\text { Hubungan } \\
\text { antar } \\
\text { sudut }\end{array}$ & $\begin{array}{l}\text { Menunjukkan contoh konsep } \\
\text { sudut dalam kehidupan sehari- } \\
\text { hari } \\
\text { Menentukan besar sudut dengan } \\
\text { menggunakan busur derajat } \\
\text { Menjelaskan hubungan antara dua } \\
\text { sudut }\end{array}$ \\
\hline $\begin{array}{l}\text { Mencoba, mengolah, dan menyaji } \\
\text { dalam ranah konkret (menggunakan, } \\
\text { mengurai, merangkai, memodifikasi, } \\
\text { dan membuat) dan ranah abstrak } \\
\text { (menulis, membaca, menghitung, } \\
\text { menggambar, dan mengarang) } \\
\text { sesuai dengan yang dipelajari di } \\
\text { sekolah dan sumber lain yang sama } \\
\text { dalam sudut pandang/teori }\end{array}$ & $\begin{array}{l}\text { Menyelesaikan } \\
\text { masalah yang } \\
\text { berkaitan dengan } \\
\text { hubungan antar } \\
\text { sudut sebagai } \\
\text { akibat dari dua } \\
\text { garis sejajar yang } \\
\text { dipotong oleh garis } \\
\text { transversal }\end{array}$ & & $\begin{array}{l}\text { Menjelaskan hubungan antar } \\
\text { sudut pada dua garis sejajar } \\
\text { Menyelesaikan masalah yang } \\
\text { berkaitan dengan hubungan } \\
\text { antar sudut }\end{array}$ \\
\hline
\end{tabular}

\section{Design (Desain)}

Tahap kedua yaitu desain (design), di mana pada tahap ini dirumuskan garis besar dari LKPD dan desain isi dari LKPD yang akan dikembangkan serta menyusun instrumen penilaian. Garis besar LKPD merupakan konsep awal LKPD sesuai dengan analisis yang telah dilakukan sebelumnya. LKPD yang dikembangkan menyajikan contoh soal dan latihan soal berkaitan dengan permasalahan-permasalahan yang sering peserta didik temui di kehidupan sehari-hari. Peserta didik diminta menyelesaikan permasalahan yang dihadapi secara individu. Selain itu, juga terdapat kegiatan praktik beserta petunjuk kerja untuk menarik minat peserta didik dalam proses pembelajaran. Desain isi LKPD berbasis PBL disajikan dalam Tabel 3. Komponen dalam LKPD berbasis PBL yang dikembangkan dalam penelitian ini meliputi sampul LKPD, profil penulis, kata pengantar, daftar isi, kompetensi inti dan kompetensi dasar, indikator pencapaian kompetensi, petunjuk penggunaan, aktivitas peserta didik, dan daftar pustaka. Aktivitas peserta didik mencakup penyajian masalah, aktivitas diskusi untuk merumuskan penyelesaian masalah, dan aktivitas untuk mengasah keterampilannya.

Tabel 3. Desain isi LKPD berbasis PBL

\begin{tabular}{ll}
\hline Tahapan PBL & Rubrik pada LKPD \\
\hline Menyajikan suatu masalah & Mencermati masalah \\
Mendiskusikan masalah & Menganalisis masalah \\
Menyelesaikan masalah & Menyelesaikan masalah \\
Berbagi informasi & Presentasi kelompok \\
Menyajikan solusi & Presentasi kelompok \\
Merefleksi & Mari mencoba \\
\hline
\end{tabular}

\section{Development (Pengembangan)}

Pada tahap pengembangan, LKPD dikembangkan berdasarkan desain yang sudah dirancang. Tahap ini bertujuan untuk mendapatkan produk awal dari LKPD yang akan dikembangkan. Tahap ini memiliki langkah-langkah 
sebagai berikut. Pertama, pengumpulan sumber atau referensi, di mana peneliti mengumpulkan sumber untuk bahan materi yang berdasar pada silabus Kurikulum 2013 sesuai dengan materi yang akan dikembangkan. Sumber atau referensi dalam hal ini berupa buku matematika yang memuat topik sudut dan kajian pustaka dari buku maupun artikel ilmiah tentang PBL yang akan dijadikan dasar dalam pengembangan LKPD. Peneliti juga mengumpulkan aset visual dari sumber online yang akan digunakan dalam pengembangan LKPD. Kedua, penulisan LKPD, di mana peneliti mulai menulis LKPD sesuai dengan garis besar LKPD yang sudah direncanakan pada tahap perancangan. Pengembangan dan layout LKPD dilakukan dengan bantuan perangkat lunak Macromedia Flash 8 dan Microsoft Word. Selanjutnya, LKPD dikonsultasikan kepada dosen pembimbing. Apabila terdapat kesalahan dalam penulisan, maka LKPD akan direvisi dan dikonsultasikan kembali kepada dosen pembimbing. Ketiga, penyusunan instrumen yang terdiri atas angket ahli materi, angket ahli media, dan angket respons peserta didik. Angket ahli materi dan media digunakan untuk kepentingan validasi LKPD sebelum LKPD tersebut diujicobakan kepada peserta didik.

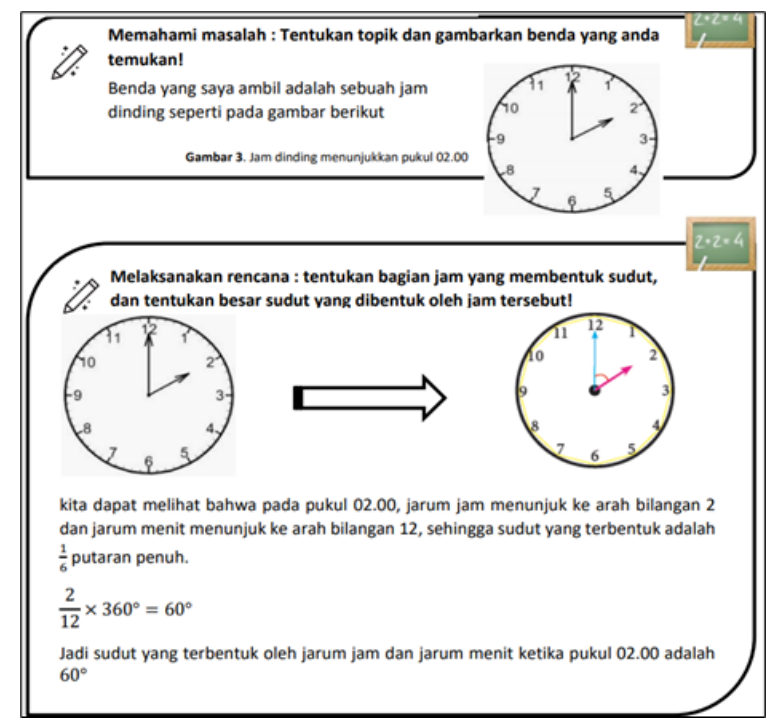

(a)

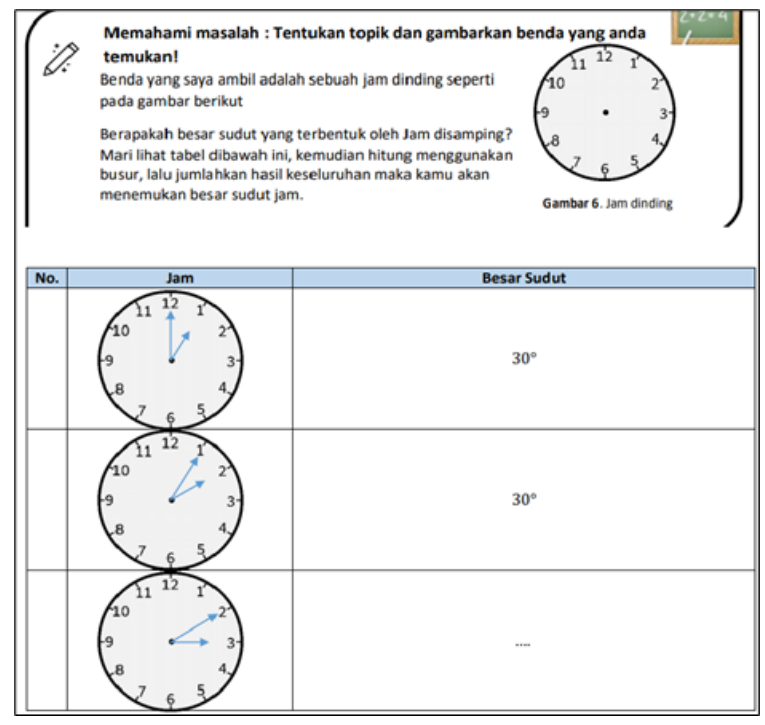

(b)

Gambar 1. (a) Aktivitas dalam LKPD sebelum revisi; (b) Hasil perbaikan aktivitas dalam LKPD berdasarkan masukan dari ahli materi

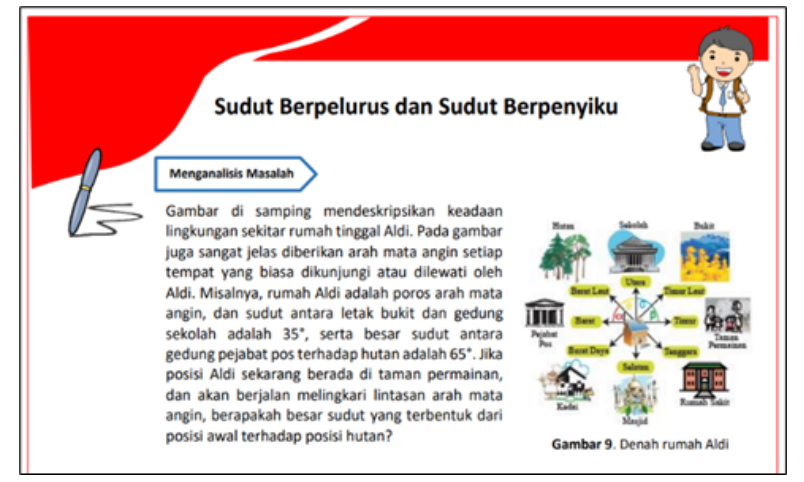

(a)

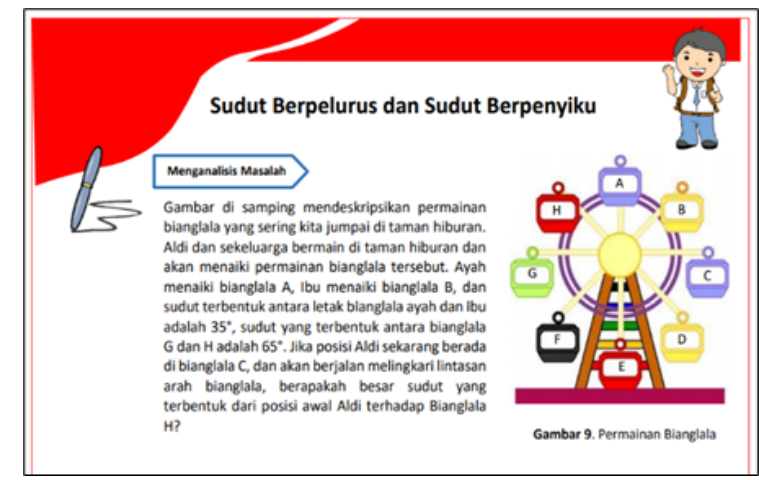

(b)

Gambar 2. (a) Ilustrasi masalah sebelum revisi; (b) Hasil perbaikan terhadap ilustrasi masalah berdasarkan masukan dari ahli media

Validasi produk dilakukan setelah produk yang dikembangkan selesai dibuat. Validasi produk sendiri dilakukan dengan tujuan agar produk yang sudah dikembangkan mendapat penilaian dan masukan dari para ahli. Masukan dari ahli materi dan ahli media digunakan sebagai acuan untuk melakukan perbaikan LKPD berbasis PBL. Masukan dari ahli materi berkaitan dengan keruntutan konsep agar lebih disesuaikan dengan kurikulum dan indikator termasuk strategi penyelesaiannya, perlunya pemberian kebebasan kepada peserta didik di awal diskusi mengenai permasalahan yang ada dalam LKPD (lihat Gambar 1 (a) dan Gambar 1 (b)), perlunya penambahan materi (jenis sudut), dan perlunya penambahan ruang dalam LKPD bagi peserta didik untuk menuliskan simpulan yang didapat 
dari penyelesaian permasalahan. Adapun masukan dari ahli media meliputi perlunya penyesuaian gambar ilustrasi dengan kondisi peserta didik SMP (lihat Gambar 2 (a) dan Gambar 2 (b)), perlunya konsistensi dalam menuliskan simbol matematika, dan perbaikan gambar ilustrasi pada soal.

\section{Implementation (Implementasi)}

Tahap implementasi merupakan tahapan untuk menerapkan LKPD berbasis PBL yang dikembangkan dalam mendukung proses pembelajaran. Pada tahap ini dilakukan uji coba LKPD kepada peserta didik kelas VII di SMP Muhammadiyah 1 Depok sebanyak 32 orang. Implementasi pembelajaran menggunakan LKPD berbasis PBL dilakukan secara online mengingat untuk saat ini sangat tidak memungkinkan untuk melakukan pembelajaran secara tatap muka dikarenakan pandemi Covid-19. Uji coba yang dilakukan pada bulan Mei 2020 ini dilakukan sebanyak tiga kali pertemuan. Pada uji coba ini, peneliti bertindak sebagai guru, sedangkan guru matematika kelas VII SMP Muhammadiyah 1 Yogyakarta bertindak sebagai observer. Proses pembelajaran dilakukan melalui grup WhatsApp dengan cara guru mengirimkan LKPD dalam format doc/pdf ke grup WhatsApp kelas VII B. Dalam proses pembelajaran melalui pengerjaan LKPD yang ada, peserta didik dapat mengikuti petunjuk penggunaan LKPD sebagai berikut: (1) Bacalah LKPD berikut dengan cermat!; (2) Pahami LKPD ini dengan sungguh-sungguh!; (3) Jika mengalami kesulitan dalam mengumpulkan informasi dan memecahkan masalah silakan bertanya langsung kepada guru via WhatsApp; (4) Kerjakan di kertas dengan menggunakan pena. Setelah selesai mengerjakan LKPD, setiap peserta didik diminta untuk mengirimkan hasil pekerjaan mereka secara online via WhatsApp.

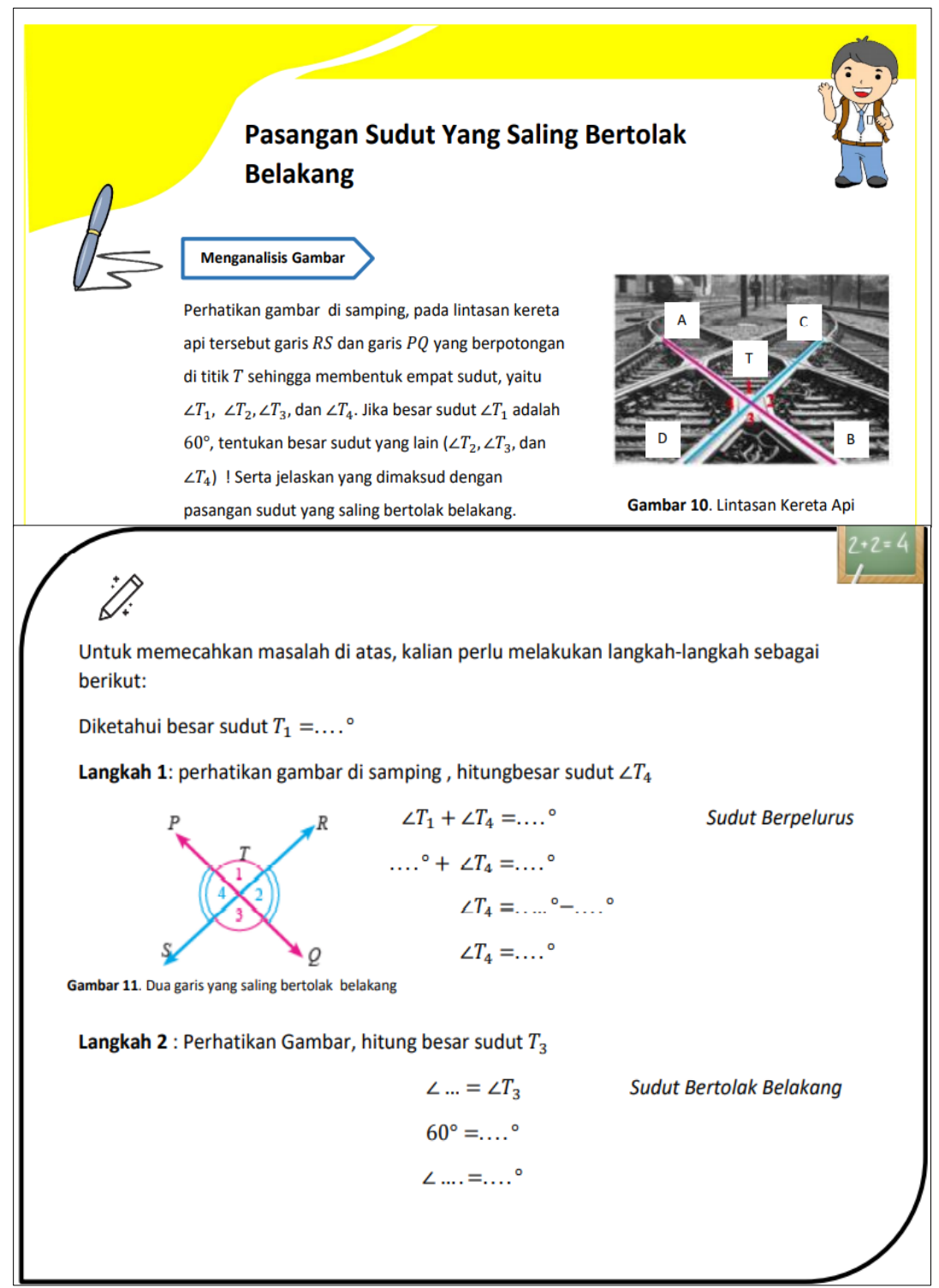

Gambar 3. Penggalan aktivitas pembelajaran dalam LKPD 
Peserta didik dituntut untuk mempelajari materi dengan melakukan aktivitas yang ada pada LKPD (contoh lihat Gambar 3) secara online. Selanjutnya peserta didik diminta untuk mengisi angket respons yang seharusnya berupa lembaran kertas dikembangkan dengan Google Forms yang bertujuan untuk memudahkan peserta didik dalam mengisi angket tanpa harus bertemu secara langsung. Pengisian angket bertujuan untuk mengetahui respons peserta didik dan evaluasi terhadap LKPD yang telah digunakan selama proses pembelajaran secara online. Hasil angket respons digunakan untuk mengetahui nilai kepraktisan penggunaan perangkat pembelajaran yang telah dikembangkan. Penilaian angket respons dilakukan menggunakan instrumen yang telah divalidasi pada tahap sebelumnya.

\section{Evaluation (Evaluasi)}

Tahap akhir penelitian ini adalah evaluasi terhadap LKPD. Evaluasi merupakan proses untuk melihat produk yang dibuat dapat digunakan atau tidak. Evaluasi sangat berperan penting untuk perbaikan produk LKPD yang dikembangkan. Evaluasi yang dilakukan adalah evaluasi oleh ahli dan evaluasi hasil validasi serta uji coba produk. Pada tahap ini dihasilkan produk berupa LKPD berbasis PBL pada materi sudut yang sudah dapat dikatakan layak sebagai bahan ajar untuk proses pembelajaran. Pada tahap evaluasi diperoleh hasil penilaian ahli materi, penilaian ahli media, dan respons peserta didik. Penilaian ahli materi disajikan dalam Tabel 4, sedangkan penilaian ahli media disajikan dalam Tabel 5.

Tabel 4. Hasil penilaian ahli materi

\begin{tabular}{llcl}
\hline Aspek penilaian & Indikator penilaian & Rata-rata skor & Kategori \\
\hline Kelayakan isi & Kesesuaian materi dengan KI dan KD & 4,0 & Baik \\
& Keakuratan materi & 4,3 & Baik \\
& Kemutakhiran materi & 3,9 & Baik \\
Kelayakan penyajian & Penyajian materi & 3,9 & Baik \\
& Koherensi dan keruntutan alur berpikir & 4,0 & Baik \\
Kesesuaian dengan PBL & Hakikat PBL & 4,0 & Baik \\
& Komponen PBL & 3,9 & Baik \\
Keseluruhan & & 4,0 & Baik \\
\hline
\end{tabular}

Berdasarkan Tabel 4 diketahui bahwa rata-rata skor keseluruhan dari penilaian dua ahli materi yaitu 4 dari skor maksimal 5. Berdasarkan penilaian ahli materi tersebut, LKPD berbasis PBL yang dikembangkan dalam penelitian ini berada pada kategori baik. Adapun berdasarkan Tabel 5 diketahui bahwa rata-rata skor keseluruhan penilaian dari ahli media yaitu 3,6 dari skor maksimal 5. Berdasarkan penilaian ahli media tersebut, LKPD berbasis PBL berada pada kategori baik.

Tabel 5. Hasil penilaian ahli media

\begin{tabular}{llcl}
\hline Aspek penilaian & Indikator penilaian & Rata-rata skor & Kategori \\
\hline Kelayakan kegrafikan & Ukuran LKPD & 3,5 & Baik \\
& Desain sampul LKPD & 3,6 & Baik \\
& Desain isi LKPD & 3,6 & Baik \\
Kelayakan bahasa & Komunikatif & 3,8 & Baik \\
& Dialogis dan interaktif & 3,5 & Baik \\
& Kesesuaian dengan perkembangan peserta didik & 3,5 & Baik \\
& Kesesuaian dengan kaidah bahasa & 4,0 & Baik \\
& Penggunaan simbol & 3,5 & Baik \\
Keseluruhan & & 3,6 & Baik \\
\hline
\end{tabular}

Berdasarkan hasil perhitungan angket respons peserta didik terhadap LKPD berbasis PBL sebagaimana dapat dilihat dalam Tabel 6, rata-rata skor hasil perhitungan data dari angket respons peserta didik adalah 4,05 dari skor maksimal 5 dan hasil ini termasuk dalam kategori baik. Dengan demikian, berdasarkan hasil penilaian ahli materi yang berada pada kategori baik, hasil penilaian ahli media yang berada pada kategori baik, dan hasil respons peserta didik yang berada pada kategori baik, dapat diambil simpulan bahwa LKPD berbasis PBL pada topik sudut ini layak digunakan. 
Tabel 6. Hasil respons peserta didik terhadap LKPD

\begin{tabular}{lcl}
\hline Indikator penilaian & Rata-rata skor & Kategori \\
\hline Respons terhadap materi & 4,07 & Baik \\
Respons terhadap bahasa & 4,07 & Baik \\
Ketertarikan terhadap LKPD & 4,01 & Baik \\
\hline
\end{tabular}

PEMBAHASAN

Penelitian pengembangan ini menghasilkan LKPD berbasis PBL pada topik sudut untuk peserta didik kelas VII SMP. Tahapan-tahapan PBL terlihat pada aktivitas-aktivitas pada LKPD. Kualitas kelayakan LKPD berbasis PBL dilihat dari penilaian ahli materi, penilaian ahli media, dan respons peserta didik. LKPD berbasis PBL yang dikembangkan memenuhi kriteria layak karena penilaian ahli materi, penilaian ahli media, dan respons peserta didik berada pada kategori baik. Menurut kelayakan yang telah ditetapkan, maka media pembelajaran atau bahan ajar matematika yang berupa LKPD berbasis PBL dengan materi sudut layak untuk digunakan oleh guru dalam pelaksanaan pembelajaran. Secara keseluruhan media pembelajaran atau bahan ajar berupa LKPD berbasis PBL ini berkualitas baik dan dapat dijadikan sumber belajar untuk materi sudut. Ditinjau dari warna yang digunakan dalam LKPD, peserta didik merasa senang belajar menggunakan media pembelajaran LKPD berbasis PBL ini.

Penelitian-penelitian sebelumnya yang berkaitan dengan penelitian ini, yaitu pengembangan perangkat pembelajaran yang termasuk di dalamnya pengembangan LKPD matematika berbasis PBL untuk peserta didik SMA menunjukkan bahwa perangkat pembelajaran valid ditinjau dari penilaian ahli (misalnya, Angraini \& Masykur, 2018; Sari, 2020). Kepraktisan perangkat pembelajaran tersebut ditinjau dari respons peserta didik menunjukkan bahwa perangkat pembelajaran praktis. Sedangkan pengembangan LKPD berbasis PBL untuk peserta didik kelas VII SMP pada topik aritmetika sosial menunjukkan hasil bahwa LKPD valid dan praktis (Ridwan et al., 2016). Validitas diketahui dari penilaian ahli, sedangkan kepraktisan ditinjau dari penilaian guru dan respons peserta didik. Pada penelitian ini berhasil mengembangkan LKPD berbasis PBL pada topik sudut untuk peserta didik kelas VII SMP. Penelitian ini memperkuat hasil penelitian-penelitian tersebut, bahwa penggunaan LKPD berbasis PBL yang valid dan praktis baik untuk digunakan dalam pembelajaran matematika untuk peserta didik SMP kelas VII.

LKPD berbasis PBL ini awalnya didesain untuk pembelajaran secara tatap muka, tetapi karena adanya pandemi maka kegiatan pembelajaran dengan LKPD ini dilakukan secara online. Hal tersebut berakibat beberapa kegiatan yang sudah dirancang tidak dapat dilakukan sesuai rencana, kegiatan diskusi yang dilakukan secara online tidak efektif, dan pemanfaatan waktu pembelajaran secara online juga kurang efektif. Solusi yang diambil adalah melaksanakan kegiatan pembelajaran secara online melalui WhatsApp. Guru memberikan memfasilitasi peserta didik dengan menggunakan LKPD yang telah dikembangkan. Guru memberikan bantuan ketika peserta didik mengalami kesulitan. Sebagai contoh, guru memberikan bantuan kepada peserta didik pada materi hubungan sudut pada dua garis sejajar. Kegiatan pembelajaran menggunakan LKPD dapat diimplementasikan mulai dari penyajian masalah, perumusan solusi oleh peserta didik, bertukar gagasan terkait solusi suatu masalah, penyajian solusi, dan refleksi. Materi yang termuat dalam LKPD disajikan secara runtut. Bahasa yang digunakan dalam LKPD adalah bahasa yang sederhana dan komunikatif. Selain itu, peserta didik juga merasa lebih bisa belajar secara mandiri dengan menggunakan LKPD yang dikembangkan dalam penelitian ini.

\section{SIMPULAN}

Hasil dari penelitian ini adalah media pembelajaran matematika berupa Lembar Kerja Peserta Didik (LKPD) berbasis Problem-Based Learning (PBL) pada topik atau materi sudut kelas VII SMP yang layak untuk digunakan dalam pembelajaran. Kelayakan LKPD dilihat dari rata-rata skor penilaian ahli materi yaitu 4,00 dari skor tertinggi 5,00 dan termasuk dalam kategori baik. Skor penilaian ahli media sebesar 3,60 dengan kategori baik. Rata-rata skor respons peserta didik terhadap penggunaan LKPD berbasis Problem-Based Learning sebesar 4,05 dan berada pada kategori baik. Dengan demikian, dapat dinyatakan bahwa media pembelajaran matematika berupa LKPD berbasis PBL untuk SMP kelas VII materi sudut layak digunakan oleh guru dalam pelaksanaan pembelajaran mandiri di rumah. Saran untuk penelitian selanjutnya, yaitu perlu adanya uji coba dalam skala yang lebih luas, guru dapat mengembangkan LKPD serupa pada topik lain, perlu ada kajian lanjut tentang LKPD yang khusus digunakan untuk pembelajaran secara online. 


\section{DAFTAR PUSTAKA}

Abidin, A. (2014). Desain sistem pembelajaran dalam konteks kurikulum 2013. Refika Aditama.

Ali, R., Hukamdad, H., Akhter, A., \& Khan, A. (2010). Effect of using problem solving method in teaching mathematics on the achievement of mathematics students. Asian Social Science, 6(2), 67-72. https://doi.org/10.5539/ass.v6n2p67

Amalia, E., Surya, E., \& Syahputra, E. (2017). The effectiveness of using problem based learning (PBL) in mathematics problem solving ability for junior high school students. International Journal of Advance Research and Innovative Ideas in Education, 3(2), 3402-3406. http://citeseerx.ist.psu.edu/viewdoc/download?doi=10.1.1.1039.1005\&rep=rep1\&type=pdf

Angraini, N., \& Masykur, R. (2018). Modul matematika berdasarkan model pembelajaran problem based learning materi pokok trigonometri. Desimal: Jurnal Matematika, 1(2), 217-228. https://doi.org/10.24042/djm.v1i2.2558

Astuti, Y. (2016). Pengembangan lembar kerja siswa (LKS) berbasis kontekstual sebagai sumber belajar di SMPN 2 Semaka untuk kelas VII pokok bahasan segi empat [Undergraduate thesis, UIN Raden Intan Lampung].

Botty, H. M. R. H., \& Shahrill, M. (2015). Narrating a teacher's use of structured problem-based learning in a mathematics lesson. Asian Journal of Social Sciences \& Humanities, 4(1), 156-164. http://www.ajssh.leenaluna.co.jp/AJSSHPDFs/Nol.4(1)/AJSSH2015(4.1-18).pdf

Chakrabarty, S., \& Mohamed, N. S. (2013). Problem based learning: Cultural diverse students' engagement, learning and contextualized problem solving in a mathematics class. WCIK E-Journal on Integration of Knowledge, 3849. https://worldconferences.net/journals/wcik/paperwcik/WCIK\%20030\%20sheila\%20chakrabarty.pdf

Choo, S. S. Y., Rotgans, J. I., Yew, E. H. J., \& Schmidt, H. G. (2011). Effect of worksheet scaffolds on student learning in problem-based learning. Advances in Health Sciences Education, 16(4), 517-528. https://doi.org/10.1007/s10459011-9288-1

Dolmans, D. H. J. M., De Grave, W., Wolfhagen, I. H. A. P., \& Van Der Vleuten, C. P. M. (2005). Problem-based learning: Future challenges for educational practice and research. Medical education, 39(7), 732-741. https://doi.org/10.1111/j.1365-2929.2005.02205.x

Isrok'atun, I., \& Rosmala, A. (2018). Model-model pembelajaran matematika. Bumi Aksara.

Jonassen, J. (2011). Learning to solve problem: A handbook for designing problem solving learning environments. Routledge.

Kemdikbud. (2013). Peraturan Menteri Pendidikan dan Kebudayaan Republik Indonesia Nomor 65 Tahun 2013 tentang Standar Proses Pendidikan Dasar dan Menengah.

Majid, A. (2012). Perencanaan pembelajaran: Mengembangkan standar kompetensi guru. Remaja Rosdakarya.

Merritt, J., Lee, M. Y., Rillero, P., \& Kinach, B. M. (2017). Problem-based learning in K-8 mathematics and science education: A literature review. Interdisciplinary Journal of Problem-Based Learning, 11(2), Article 3, 1-12. https://doi.org/10.7771/1541-5015.1674

Muslim, M., Ikhsan, M., \& Abidin, T. F. (2018). Student difficulties in solving high order thinking skills (HOTS) problem on geometry problems viewed from the cognitive styles. Proceedings of the 8th Annual International Conference (AIC) on Social Sciences, 310-315. http://jurnal.unsyiah.ac.id/AICS-Social/article/view/12956

Nasrullah, A., Marlina, M., \& Dwiyanti, W. (2018). Development of student worksheet-based college e-learning through Edmodo to maximize the results of learning and motivation in economic mathematics learning. International Journal of Emerging Technologies in Learning, 13(12), 211-229. https://doi.org/10.3991/ijet.v13i12.8636

Niken, N., Susanto, S., \& Setiawan, T. B. (2012). Penerapan pembelajaran matematika melalui model pembelajaran reciprocal dalam mengatasi kesalahan siswa menyelesaikan soal matematika kelas IX SMP N 1 Pakusari pokok bahasan statistika semester ganjil tahun ajaran 2012/2013. Kadikma: Jurnal Matematika dan Pendidikan Matematika, 3(3), 95-108. https://jurnal.unej.ac.id/index.php/kadikma/article/view/1016 
Oktaviana, D., \& Prihatin, I. (2019). Pengembangan bahan ajar matematika berbasis buku fabel berkarakter untuk siswa SMP. SAP (Susunan Artikel Pendidikan), 3(3), 182-189. https://doi.org/10.30998/sap.v3i3.3588

Perwitasari, D., \& Surya, E. (2017). The development of learning material using problem based learning to improve mathematical communication ability of secondary school students. International Journal of Sciences: Basic and Applied Research, 33(3), 200-207. https://gssrr.org/index.php/JournalOfBasicAndApplied/article/view/7382

Prastowo, A. (2011). Panduan kreatif membuat bahan ajar Inovatif: Menciptakan metode pembelajaran yang menarik dan menyenangkan. Diva Press.

Presiden Republik Indonesia. (2003). Undang-Undang Nomor 20 Tahun 2003 tentang Sistem Pendidikan Nasional.

Puspendik. (2019). Laporan hasil ujian nasional: Penguasaan materi ujian nasional. Kementerian Pendidikan dan Kebudayaan. https://hasilun.puspendik.kemdikbud.go.id/

Relia, L. (2016). Keterkaitan antara Lembar Kerja Peserta Didik (LKPD) matematika dengan model pembelajaran kreatif, inovatif, dan produktif (KIP). Prisma: Prosiding Seminar Nasional Matematika, 97-103. https://journal.unnes.ac.id/sju/index.php/prisma/article/view/21435

Ridwan, R., Zulkardi, Z., \& Darmawijoyo, D. (2016). Pengembangan perangkat pembelajaran aritmetika sosial berbasis problem based learning di kelas VII SMP. Jurnal Elemen, 2(2), 92-115. http://ejournal.hamzanwadi.ac.id/index.php/jel/article/view/180

Risfalidah, R., Rosidin, U., \& Sutiarso, S. (2019). Pengembangan LKPD berbasis problem based learning ditinjau dari disposisi dan kemampuan komunikasi matematis. Jurnal Penelitian dan Pembelajaran Matematika, 12(2), 271-283. http://dx.doi.org/10.30870/jppm.v12i2.6171

Salyani, R., Amsal, A., \& Zulyani, R. (2018). Pengembangan buku saku pada materi reaksi reduksi oksidasi (redoks) di MAN Model Banda Aceh. Jurnal IPA \& Pembelajaran IPA, 2(1), 7-14. https://doi.org/10.24815/jipi.v2i1.10736

Sanjaya, W. (2006). Strategi pembelajaran berorientasi standar proses pendidikan. Kencana Prenada Media Group.

Sari, S. M. (2020). Pengembangan perangkat pembelajaran problem based learning (PBL) dalam pembelajaran matematika di SMA. Jurnal Serambi IImu, 21(2), 211-228. https://doi.org/10.32672/si.v21i2.2235

Siagian, M. V., Saragih, S., \& Sinaga, B. (2019). Development of learning materials oriented on problem-based learning model to improve students' mathematical problem solving ability and metacognition ability. International Electronic Journal of Mathematics Education, 14(2), 331-340. https://doi.org/10.29333/iejme/5717

Sindhunata, S. (2000). Menggagas paradigma baru pendidikan: Demokratisasi, otonomi, civil society, globalisasi. Kanisius.

Siregar, Y. (2013). Kompetensi guru dalam bidang strategi perencanaan dan pembelajaran matematika. Formatif: Jurnal IImiah Pendidikan MIPA, 3(1), 39-48. https://doi.org/10.30998/formatif.v3i1.114

Sugiyanto, Y., Hasibuan, M. H. E., \& Anggereni, E. (2018). Pengembangan Lembar Kerja Peserta Didik (LKPD) berbasis kontekstual pada materi ekosistem kelas VII SMPN Tanjung Jabung Timur. Edu-Sains: Jurnal Pendidikan Matematika dan Ilmu Pengetahuan Alam, 7(1), 23-33. https://doi.org/10.22437/jmpmipa.v7i1.7279

Sugiyono, S. (2016). Metode penelitian pendidikan pendekatan kuantitatif, kualitatif, dan R\&D. Alfabeta.

Turmudi, T. (2010). Penalaran dalam geometri: Pelatihan guru-guru matematika di Manokwari, Papua Barat. Universitas Pendidikan Indonesia.

Uden, L., \& Beaumont, C. (2006). Technology and problem-based learning. Information Science Publishing.

Wardhani, I. S. (2013). Pengembangan buku siswa dengan pendekatan pendidikan matematika realistik (PMR) pada topik garis dan sudut di SMP. Inspirasi: Jurnal IImu-ilmu Sosial, 8(15), 90-104.

http://dx.doi.org/10.29100/insp.v8i15.281

Widoyoko, E. P. (2017). Evaluasi program pembelajaran: Panduan praktis bagipendidik dan calon pendidik. Pustaka Pelajar. 